\title{
VIEWPOINTS
}

\section{Caliph and the 'Islamic State' - Lessons of History}

\author{
Karim Douglas Crow*
}

\author{
The succession (khiläfah) to Prophecy will last for thirty years, \\ afterwards Kingly-rule is given to whomever (God) wills. \\ - God's Messenger Muhammad [the hadìth al-Safinah] ${ }^{1}$
}

The declaration of a so-called 'Islamic State' in parts of Syria and Iraq on 27 June 2014/1 Ramaḍān 1435 by Sunni Jihadist renegades led by Abu Bakr al-Baghdadi (a.k.a. 'Awwād Ibrāhīm 'Alī al-Badrī, or Abū Du'ā', born 1971)² claimed a universal authority throughout the Muslim ummah in the manner of the caliphs of old. The veteran Iraq observer Patrick Cockburn objectively describes IS to be "the most powerful and effective extreme jihadi group in the world...violent and sectarian... highly fanatical." Abu Bakr sends a powerful message resonating in the minds of militants across the Islamic world, by denying the legitimacy of the political and religious leaders of 1.6 billion Muslims. "I do not promise you, as the kings and rulers promise their followers and congregation, luxury, security and relaxation," he said in his khutbah in Mosul; "instead I promise you what Allah promised his faithful followers" [i.e. Paradise through martyrdom]. In his audio message posted online on 1 July 2014, Ibrahim stated it was the duty of all Muslims to immigrate to his self-styled 'Islamic State', and he named a list of countries from the Central African Republic to Myanmar and Xinjiang (in Chinese Turkistan) where violations are being committed against Muslims. "Your brothers on every piece of this earth are waiting for you to rescue them," he declared; "By Allah, we will take revenge! by Allah we will take revenge! even if after a while."

Most official state Muslim religious authorities around the world have denounced this Islamic State as illegitimate, dangerous and divisive. The Jordanian religious scholar Abū Muḥammad al-Maqdisī, deemed one of al-Qaeda's spiritual leaders, branded Ibrahim's Islamic State as "deviant" and contrary to the principles of Shari'ah law, and challenged the basis of al-Baghdadi's claims: "Is this 'caliphate' going to be a safe haven for all the vulnerable and a shelter for every Muslim? Or will this name become a hanging sword over Muslims who disagree with them?" This newly risen proto-caliphate headquartered in the eastern Syrian provincial capital of al-Raqqah is seen to be an aberration, a hopeless dead end signalling perverse misguidance and descent into brutality. They seek to recreate a moral, 
social and political order sourced in divine guidance, while their immoral means poison their ends.

Nevertheless, there remains the lingering appeal of an authentic Islamic polity or form of governance which could embody the principled ideals of Islam: social distributive justice, a moral economy, impartial egalitarian law, and repelling culturalmilitary penetration by Euro-American marketisation. Many Muslims still associate the very concept of 'caliphate' with a golden age when Islam was a powerful and successful world empire; while some dream of erasing the colonial borders of the Arab world to unify the Muslims and reverse the invasive penetration of Western dominance. Combined with this nostalgia is the expectation that enforcing Shari'ah law would help solve the problems modernity has wrapped up Muslim societies.

Since the mid-twentieth century small groups of cult-like radicals hoped for a restored caliphate, but this never achieved any real traction with the world's Muslims. The global Jihadist project galvanized by al-Qaeda from the 1990s advanced this dream, with Mulla Omar Uruzgani of Afghanistan even proclaimed a "caliph" by the Taliban and al-Qaeda. The al-Qaeda spin-off JI (Jama'at Islamiah) in Indonesia that perpetrated the Bali bombings on 1 October 2005, also echoed the dream of creating a caliphal polity in South East Asia. Now the black banner of IS is raised as a rallying point for militants from Indonesia to Nigeria, and several al-Qaeda affiliates from Yemen to Sinai to North Africa have declared themselves to be 'emirates' in copycat fashion. IS cells are uncovered in Malaysia, Australia, and Germany raising the alarm of 'martyrdom operations' in several countries. Meanwhile the United States led Arab coalition is air bombing al-Raqqah and Jihadist sites in Syria and Iraq.

\section{Recalling History}

It is instructive that al-Raqqah in eastern Syria was twice the site of Muslim caliphs in the second century of Islam. Just southwest of al-Raqqah in the east Syrian steppe by the middle Euphrates lies the ruins of al-Rașāfah (known in late Roman times as Sergiopolis), a thriving caravan depot and Byzantine border fortress against the Sasanian Persians, whose massive 1600 feet long walls still stand around the Basilica of Saint Sergius ${ }^{3}$. Its strategic location at the crossing of caravan routes connecting Aleppo and Anatolia with northern Iraq was advantageous. In the eighth century the Umayyad Caliph Hishām b. 'Abd al-Malik (r. 724-743) made this city his favoured summer residence where he built several palaces just outside the city walls, as well as a mosque near the shrine of St. Sergius and a market complex.

Half a century later in 796 the fifth Abbasid caliph Hārūn al-Rashīd (r. 786-809) decided to move his court and seat of government from Baghdad to al-Raqqah. There caliph Hārūn spent twelve years or most of his reign, only returning to Baghdad for a short visit once. Raqqah was well situated for the Abbasid imperial centre at the height of power: communication lines through the Euphrates to Baghdad, through 
the Balikh river to the north, and through Palmyra to Damascus were excellent. From al-Raqqah any rebellion in Syria and the middle Euphrates area towards Iraq could be controlled. The splendid life at Hārūn's court is enshrined in poetry and legend, celebrated also in the Arabian Nights. Hārūn's two sons and future Abbasid caliphs al-Amīn (r. 809-813) and the redoubtable caliph al-Ma'mūn (r. 813-833) both grew up in al-Raqqah.

The city was abandoned for much of the Ottoman period, until its resettlement in the late $19^{\text {th }}$ century. Since Syrian independence it grew rapidly becoming home to almost a quarter of a million inhabitants. Thus the choice of al-Raqqah as military and administrative centre was a calculated move by IS, and its rapid advance west toward Aleppo, north to the border with Turkey, and east through Iraq to Mosul and Diyala province near the Iranian border was accomplished by following the twinrivers. Along its way IS captured oil wells, water resources and dams, much war materiel and amassed fresh recruits. The territory between the Tigris and Euphrates forms the heartland of this proto-caliphal realm stretching from the borders of Turkey to Kurdistan and Iran - as world media repeats: "vast swathes of land."

Another motive for this choice was the impressive tomb complex in al-Raqqah, sponsored and paid for by the Islamic Republic of Iran, for three of the Prophet's most famous Companions: 'Ammār b. Yāsir, who was slain fighting in 657 for the fourth caliph 'Alī at the battle of Siffīn ${ }^{4}$ against a Syrian army commanded by Mu'āwiyah b. Abī Sufyān (who became the sixth caliph); and the spiritual icon Uways al-Qaranī; and Ubay b. Ka'b (d.649) whose Qur'an readings were influential. The magnificent shrine refurbished for 'Ammār was designed to serve as a visitation site for Iraqi and Iranian pilgrims honouring a venerated saint-with the boom in Iranian pilgrimage to Syria from the $1980 \mathrm{~s}^{5}$. Work commenced in 1988 well before the Baathist Asad regime hurled Syria into chaos and bloodshed in 2011. (Today out of a total Syrian population of 22 million, three million are refugees and six and a half million are internally displaced.) During the 1990s to 2000s al-Raqqah hosted a series of events sponsored by Iran, with conferences and lectures devoted to Shi' ${ }^{6}$ h themes and Iranian-Syrian fellowship. When Abu Bakr al-Baghdadi took control of al-Raqqah in March 2013 in concert with Jabhat al-Nușrah [at that time still under his umbrella of 'Islamic State of Iraq \& Sham' - formerly 'al-Qaeda In Iraq'], they seized the shrine and turned it into a headquarters for issuing fatwas. His people purged the new structure around 'Ammār's tomb of Iranian symbols. Tomb visitation is anathema to neo-Wahhabi puritans, and tomb destruction part of their repertoire of hatred as they recently made abundantly clear in Mosul. Such destruction fuels the sectarian-directed proxy conflicts gathering renewed energy across the Islamic world. So much for the history of al-Raqqah-reminding us that history repays its devotees with useful insights. 


\section{Can the Caliphate Return?}

The Abbasid caliphate ruled central Islamic lands until the Mongol conquest of Baghdad in 1258. Afterwards with the Mamluk Sultans in Egypt, and then the Ottoman Sultans who made Istanbul the capital of their powerful empire, no one ever took seriously their claims to a universal caliphate, despite occasional flowery hyperbole calling the Ottoman ruler 'caliph' or more often 'world emperor.' It was the great Ottoman warlord Sultan Selim I, father of Suleiman the Magnificent, who brought the title 'caliph' back as a souvenir of his conquest of Mamluk Egypt. Along with this grandiose title Selim brought the relics of the Prophet Muhammad he confiscated from the Hasanid Sharīfs in the Hijāz and now displayed in Topkapı Serai, serving as legitimating emblems of his dynasty's authority. In actuality the Sultans functioned more as secular monarchs. True: the penultimate Ottoman Sultan Abdul Hamīd II (r. 1876-1909) who was concerned about European encroachment on Ottoman and Muslim lands, declared himself as caliph to garner support against European encroachment, to some effect in British colonial India.

Yet Shaykh Ahmad al-Damanhūrī the $18^{\text {th }}$ century rector of al-Azhar, foremost center of Sunni learning, wrote an essay in which he bluntly stated that the caliphate had ended in 1258 - and that neither the Mamluk 'shadow caliphate' (eighteen of them held office from 1261-1517) nor the Ottoman emperors were truly caliphs ${ }^{6}$. The Sunni caliphate had lapsed when the army of Hulagu Khan demolished Baghdad in February 1258, killing the last Abbasid caliph AL-Musta'șim by rolling him in a carpet and trampling him to death under their horses' hoofs - the Mongol's mark of respect for a man of royal blood. When Kamal Ataturk abolished the 'caliphate' in 1924, it had already ceased to exist over six hundred fifty years previous.

Today Sunni Islam lacks any formal religious and administrative centre while Muslim societies are organised on the basis of the nation-state. Majority Sunni Muslim nations appoint a Mufti or leading jurist as the highest religious legal authority to administer what remains of the Shari'ah. The Mufti is almost always a state functionary. Do the failures of official Islam in political, economic, and military spheres open a vacuum that would-be caliphs or emirs are seeking to fill?

\section{Notes}

* Karim Douglas Crow is a Principal Research Fellow at IAIS Malaysia. His current projects involve research into ethical issues joining Muslim with Euro-American societies, and civilisational aspects of contemporary Islamic and Asian societies in the light of globalised trends. He is completing several books: American Evangelicals: Cultural Shifts, Militarism, and the Coming of Messiah; 'When God Created Wisdom': ‘Aql Creation Narratives in Islam (forthcoming, Leiden: Brill); and his lifetime project Lamp of Knowledge: the Career and Teaching of Ja'far al-Sādiq (d.148/765 CE). 
1. From Abū Dāwūd, Sunan, and al-Tirmidhī, Șahịh ; for the ideological role of this utterance distinguishing between the rule of the Four Rightly-guided Caliphs, and Umayyad tyranny, see Karim D Crow and Ahmed Kazemi Moussavi, Facing One Qiblah (Singapore: Pustaka Nasional, 2005) p. 78 \& pp. 180-181 note 100.

2. Abu Bakr has degrees in Islamic Studies, including poetry, history and genealogy, from the Islamic University of Baghdad; he was a preacher in Diyala province north-east of Baghdad, where after the U.S. invasion of 2003 he led his own armed insurgency group. Between 2005 and 2009 he may have been a prisoner of the Americans in Bocca Camp in southern Iraq. See Patrick Cockburn, "Who Are ISIS? The Rise of the Islamic State in Iraq and the Levant", The Independent, 16 June, 2014.

3. Elizabeth K. Fowden, The Barbarian Plain: Saint Sergius Between Rome and Iran (Berkeley: University of California Press, 1999), on the cult of the martyr St. Sergius in Syria and Mesopotamia, regarded by the Ghassanid Arabs (or Jafnids) as their patron saint. On caliph Hishām's building projects see Alan Walmsley, Early Islamic Syria: an Archaeological Assessment (London: Duckworth, 2007).

4. Siffin is forty kilometers west of al-Raqqah. Uways was an ascetic Yamani with whom the Prophet is said to have communicated telepathically, and was deemed patron saint of al-Raqqah; Ubay was one of the Prophet's secretaries. The identification of their tombs at al-Raqqah relied on popular tradition, and may be conjectural.

5. Consult the important studies of this shrine and its recent history by Myriam Ababsa, Raqqa: territoires et pratiques sociales d'une ville syrienne (Beirut: Presses de l'Institut Français de Proche-Orient, 2009) pp. 225-254; and her study "Significations territoriales et appropriations conflictuelles des mausolées chiites de Raqqa (Syrie)", in Les Pelerinages au Maghreb et au Moyen-Orient, eds. Sylvia Chiffoleau \& Anna Madœuf (Damascus: IFPO, 2005) pp. 110-130; both are available online at - http://books.openedition.org/ifpo/. See also Martin Kramer's useful synopsis of her work posted 16 April, 2013, at: http://www. martinkramer.org/sandbox/2013/04/the-shiite-crescent-is-broken/.

6. Aḥmad al-Damanhūrī, al-Naf" al-Ghazīr fi Șalāh al-Sulțān wa l-Wazīr, Egyptian National Library, Taymūr Ijtimā', MS 34, folio 10; cited by Juan Cole, "The Debacle of the Caliphates", 30 June 2014, at: http://www.juancole.com/2014/06/ caliphates-baghdadis-grandiosity.html. 